\title{
Atasözlerinde Saldırgan Mizah Tarzının İşlevi
} AHMET AKGÖL*

\section{Öz}

Mizahi atasözlerinde, varlığı oldukça dikkat çeken saldırgan mizah tarzının, atasözlerindeki işlevinin ne olduğunu ve atasözlerinde hangi ilişkiler sonucu yaratıldığını anlamak için bu çalışmada atasözleri ve mizah arasındaki ilişki incelenmiştir. Çalışmaya dâhil edilen atasözleri Ömer Asım Aksoy'un Deyimler ve Atasözleri 1 adlı eserinden örneklem yoluyla seçilmiş ve çalışmanın amacı doğrultusunda incelenmiştir.

İnceleme aşamasında, saldırgan mizahın yaratılmasına sebep olan eksikliklerle mizahi unsurlar arasındaki ilişkiye değinilmiş ve mizahi unsurlar mizah kuramları bağlamında değerlendirilmiştir. Elde edilen veriler, eksikliklere ve mizah kuramlarına göre ayrı ayrı sınıflandırılmıştır. Sınıflandırma sonucuna göre atasözlerindeki saldırgan mizahın işlevi ve hangi ilişkiler sonucu yaratıldığ1 tartışılmıştır. Tartışma sonucuna göre atasözlerinde var olan saldırgan mizahın, atasözlerinin taşıdığı mesaja dikkat çekmek, mesajın; anlaşılmasına, hatırlanmasına ve aktarılmasına yardımcı olmak gibi bir işlevi olduğu ayrıca saldırgan mizahın genellikle bir hayvan veya üreme ve boşaltım organlarıyla yapılan ilişkilendirmeler başta olmak üzere; küçük düşürmeye dönük bir anlayışla yaratıldı̆̆ı tespit edilmiştir.

Anahtar sözcükler: Atasözleri, saldırgan mizah tarzı, mizah, mizah kuramları, rahatlama kuramı, üstünlük kuramı.

\section{THE FUNCTION OF AGGRESSIVE HUMOUR STYLE IN PROVERBS}

\section{Abstract}

In this study, the relation between proverbs and humour was examined to understand what the function of the aggressive humour style, which takes attention in humorous proverbs, is in proverbs and how they are created as a result of certain relations. The proverbs included in the study were selected from the book "Proverbs and Maxims 1" written by Ömer Asım Aksoy with random sampling method, and were examined for the purpose of the study.

In the examination stage, the relation between humorous elements and the missing points that caused the creation of aggressive humour were determined, and the humorous elements were assessed in the context of humour theories. The data were classified according

\footnotetext{
* Muğla S. K. Üniversitesi Sosyal Bilimler Enstitüsü Halkbilim Doktora, orcid.org/0000-0002-3176-1262, akgollahmet@gmail.com. Gönderim tarihi: 04.04.2018 Kabul tarihi: 15.05.2018
} 
to the missing points and humor theories separately. According to the classification results, the issue of after which relations the humorous elements were created and the function of aggressive humor in proverbs were discussed. According to the discussion results, it was determined that the aggressive humor in proverbs were created for the purpose of highlighting the message carried by the proverbs; helping the message to be understood, remembered and conveyed. It was also determined that aggressive humor is made by associating it with an animal or reproductive and excretory organs for the purpose of attacking and humiliating someone.

Keywords: Proverbs, aggressive humor style, humor, theories of humor, relaxation theory, superiority theory.

\section{GíRIŞ}

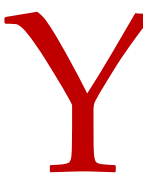

azılı ilk mizah ürünleri arkeolojik araştırmalar sonucunda Sümer uygarlığına ait metinlerde bulunmuştur. Metinlerde tespit edilen atasözü ve değişler insanların o zaman neye güldükleri hakkında araştırmacılara somut deliller sunmuştur (Özdolap, 2015, s. 4). 3500 yıl önceye ait bu metinler, çalışmamızın konusu olan atasözleri ve mizah arasındaki ilişkinin yazılı ilk örnekleridir. Ancak bu ilişkinin dil ve gülme ortaya çıktığı zamanlardan beri var olduğunu tahmin etmek güç değildir.

Başta Ömer Asım Aksoy olmak üzere birçok araştırmacı, atasözlerinin toplumun deneyimlerine ve gözlemlerine göre ortaya çıkmış, toplumun sosyal ve kültürel hayatı hakkında bilgi alınabilecek bir sözlü kültür unsuru olduğuna dair görüş birliğine varmışlardır. Tarihten günümüze mizahı araştıran araştırmacılarda, her ne kadar tam olarak mizah hakkında görüş birliğine varmasalar da, mizahın toplumun sosyal ve kültürel dinamiklerinden beslendiği hakkında hemfikirlerdir. Toplumun sosyal ve kültürel hayatını birebir yansıtan atasözlerinin, toplumun sosyal ve kültürel dinamiklerinden beslenen mizahı da içinde barındırması normaldir. Diğer bir taraftan sözlü kültür devirlerinde mahkeme görevi gibi ${ }^{1}$ ciddi ve hayati işlevi olan atasözlerinde eğlence ile yakın bir ilişkisi olan mizahın kullanılması ve bu mizahın yer yer saldırgan bir tavırla yaratılması bir o kadar da dikkat çekicidir.

Atasözleri, bireyin okulu ve yaşama kılavuzu niteliğindedir. Sahip olduğu bilgileri müzikal ve kalıpsal özellikleriyle konserve hâline getirerek gelecek kuşaklara aktarılmasını sağlamaktadır (Çobanoğlu, 2003, s. 2). Mizah ise insanoğlunun gülme refleksinin verdiği hazzı keşfettikten sonra o hazzı tetiklemek için yarattı̆̆ı bir kültürdür (Akgöl, 2016, s. 15).

\footnotetext{
1 "Sözlü kültürlerde yasalar bile, kalıplaşmış deyişlere, atasözlerine yerleşmiştir; bunlar yalnız yasa dilinin süsü değil yasanın özüdür. Zaten sözlü kültürlerde çoğu kez yargıcın görevi, huzuruna getirilen resmi anlaşmazlığı adil bir karara bağlamak için dava konusuyla ilgili atasözlerini beyan etmektir" (Ong, 2010, s. 51)
} 
Gülme üzerine Antik Yunan döneminden bu yana fikirler olmasına rağmen nasıl meydana geldiğine dair net bir görüş ileri sürülememiştir. Ancak D. H. Mongro'nun gülme hakkında ortaya atılan görüşleri toparladığı sınıflandırması gülme ve mizah araştırmalarında büyük yardımı dokunmaktadır. Mango mizah hakkındaki görüşleri Üstünlük, Uyumsuzluk ve Rahatlama olarak tanımlayabileyebileceğimiz kısımlara ayırmıştır² (Feingberg, 2004, s. 105). Kendilerine karşı fiziksel cesaret zekâ ya da başka insani özellik konusunda üstünlük duyduğumuz kişilere güldüğümüzde bu üstünlük kuramı ile bir olayda veya durumda umulanın tersi bulunduğunda o sonuç insanın gülmesine neden olduğunda bu, uyumsuzluk kuramı ile açılanmaktadır ((Morreall, 1997, s. 22; Özünlü, 1999, s. 20). Rahatlama kuramı ise Freud'un görüşleri çerçevesinde doğmuştur. İnsanların duygularına ve cinsel güdülerine uygulanan sansür ve ilkel güdülerinin toplum tarafından reddi, insana çetin geldiğinde bu durumda mizah yardıma koşar ve onun yardımıyla insan kaybettiği mutluluğu tekrar bulur (Freud, 1999, s. 80).

Araştırmacıların dikkati sadece mizahın neden oluştuğu değil aynı zamanda mizahın girdiği biçimler de çekmektedir. Martin, PuhlikDoris, Larsen, Gray ve Weir bireylerin yarattıkları mizaha göre dört farklı mizah tarzı olduğunu belirlemişlerdir. Bunlar; Kendini geliştirici, katılımcı, saldırgan ve kendini yıkıcı mizah tarzıdır (Yerlikaya, 2009, s. 29). Mizah tarzlarından en fazla dikkat çekeni belki de kullanılanı saldırgan mizah tarzıdır. ${ }^{3}$ Saldırgan tarzın bize göre iki şekli vardır. Bunlardan birincisi kişinin rahatlamak amacıyla karşı tarafa takındığı saldırgan tavır, ikincisi ise kişinin karşı taraftan kendisini düzeltmesini beklediği için takındığı saldırgan tavır. Birinci kısım Freud'un görüşlerine dayandırılmaktayken, ikinci kısım Bergson 'un görüşlerine dayandırılmaktadır. (Akgöl, 2016, s. 70-71)

$\mathrm{Bu}$ çalışmada atasözlerinde oldukça dikkat çeken saldırgan

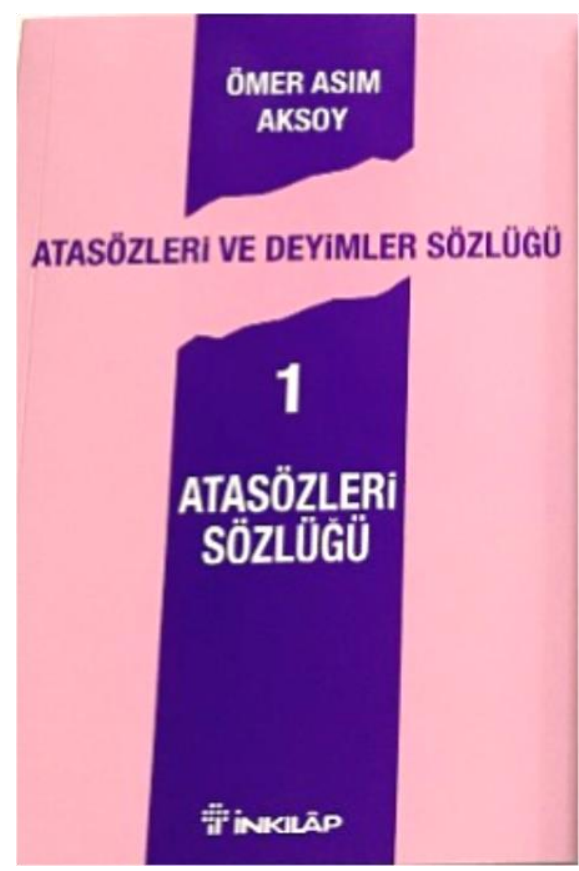
mizahın nasıl bir işlevi olduğu tespit edilecektir. Böylelikle son derece ciddi ve hayati bilgiler taşıyan atasözleri ile ona zıt özelliklere sahip olan saldırgan mizah tarzının neden bir araya geldiği anlaşılmış olacaktır. Çalışmada incelenmek için kullanılacak olan atasözleri, akademide oldukça kabul gören bir kaynak olduğu için Ömer Asım Aksoy'un Deyimler ve Atasözleri Sözlü̆̆̈̈̈ 1 adlı eserinden örneklem yoluyla seçilmiştir.

\footnotetext{
2 Mango'nun dengesizlik olarak tanımladığı durumlar uyumsuzluk kuramına dâhil edilmiş, kısıtlamadan kurtulma şeklindeki tanımı ise rahatlama olarak değiştirilmiştir.

${ }^{3}$ Bk: Sanders, B. (2001). Kahkahanın Zaferi- Yıkıcı Tarih Olarak Gülme. (K. Atakay. Çev.). İstanbul: Ayrıntı Yayınları.
} 


\section{ATASÖZLERİNIN MIZZAHİ YÖNDEN İNCELENMESI}

Bu bölümde Ömer Asım Aksoy'un hazırladığı sözlükten örneklem yoluyla seçilen atasözleri mizahi yönden incelenecektir. İnceleme amacıyla seçilen atasözlerinin saldırgan bir mizah tarzına sahip olduğu 2016 yılında hazırladığımız ve elli dokuz atasözünü incelediğimiz yayımlanmamış yüksek lisans tezimizde ${ }^{4}$ tespit edilmiştir.

Ömer Asım Aksoy'un sözlüğünden alınan mizahi unsurlar barındıran atasözleri, bu bölümde sözlükteki sıralama bozulmadan açıklamaları ile beraber alınacak ve incelenecektir. Aksoy'un sözlügüündeki açıklamaların bazılarının anlaşılır olmadığı tespit edilmiştir. Bu açıklamaların yanına parantez içerisinde düzeltmeler verilecektir.

Bazı atasözlerinin mizah barındırıp barındırmadığı ilk bakışta anlaşılmayabilir. Bu nedenle mizahı yaratan ilişkileri veya kavramların açılanması gereken atasözlerinde kavramların ve ilişkileri arka planları hakkında kısa açıklamalar yapılmıştır. Ele alınan atasözünde mizahı yaratan kavramların arka planlarının anlaşılması için yapılan açıklamalar veya ilişkilendirmelerin kolayca kavranmasını sağlayacak bilgiler verildikten sonra; atasözünde bahsedilen kişinin veya durumun hangi kavramlarla ilişkilendirdiğini ve bu kavramlarla gelen çağrışımların sözlü mizahın ilk amacı olan akılda canlandırmaya nasıl yardımcı olduğu tespit edilecektir. Bu aşamalardan sonra elde edilen veriler sonucunda ele alınan atasözündeki mizahi unsurun nasıl bir eksikliği telafi ettiği belirlenecek ardından, hangi mizah kuramını temsil ettiği tespit edilecektir. Mizahi unsurun telafi ettiği eksikliği ve bu eksikliği nasıl telafi ettiğini ayrıca dâhil olduğu kuramı bilmek atasözünün sınıflandırılmasına ve saldırgan mizah tarzının atasözündeki işlevinin anlaşılmasına yardımcı olacaktır.

1. Atasözü: Açık göte herkes tükürür (s. 62)

1. Atasözünün Anlamı: "Utanç verici tiksindirici davranışları herkes ayıplar, tiksinti ile karşılar." (s. 62)

\section{Atasözünün Mizahi Yönden İncelemesi}

Atasözünde gülmeyi yaratan unsur olan göt, mahrem bir organdır ve dünyadaki hemen hemen bütün topluluklarda bu organ kıyafetlerle kapatılır. Vücudun bu kısmını kapatmayan bir kişi toplum tarafından farklı şekillerde ayıplanabilir. Ayıplama şekillerinden birisi de tükürmektir. Sosyal bir alg1 olarak tükürük tiksinilen, iğrenç olarak kabul edilen bir vücut salgısıdır. Karşılaşılan ayıp ya da iğrenç bir şeye tükürük layık görülür. Atasözünde "utanç verici ve tiksindirici davranış" götle, "tiksinti ile karşılama ve ayıplama" ise tükürme eylemi ile ilişkilendirilmiştir. Göt, kelimesini komik yapan duruma, Freud, açık saçıklık der ve hedefinin karşı tarafı soyundurmaya yönelik olduğunu söyleyerek devam eder. Bir kişinin

\footnotetext{
${ }^{4}$ AKGÖL, Ahmet.(2016). Atasözlerinde Mizahın İşlevi. (Basılmamış ) Yüksek Lisans Tezi. Muğla
} 
açık saçık sözlerden zevk almasının ve o sözlere gülmesinin nedenini toplumun kişiye uyguladığı cinsel baskının bir çeşit salınımı olarak açıklar (Freud, 1999, s. 77).

Freud'a göre espri, soyut ve zararsız türden değilse, saldırı, yergi ve savunma amacina veya teşhir amacina yönelik açık saçıklık hedefini güder (Freud, 1999, s. 77). Bu atasözünde vücudun göt kısmıla bir açık saçıklık, tükürme eylemiyle de saldırganlık göze çarpmaktadır. Mahrem bir şeyin saklanmaması ahlak anlayışına göre bir eksikliktir ve bu eksiklik göt kelimesinin bahsiyle yaratılan mizah ile telafi edilmiştir. Bu bağlamda atasözündeki mizahi unsur rahatlama kuramı ile ilişkilendirilebilir ve tükürme eylemi bir saldırganlık eylemi olduğu için atasözündeki mizah tarzı da saldırgan mizah tarzı olarak nitelendirilebilir.

2. Atasözü: Eşeğe (katıra) cilve yap demişler, çifte (tekme) atmış. (s. 135)

2. Atasözünün Anlamı: Kaba ve ahmak kişilerin hoşa gitsin diye söylediği sözler ve yaptığ 1 işler, kaba ve incitici olur. (s. 135)

\section{Atasözünün Mizahi Yönden İncelemesi:}

Toplumda, kullanıldığı işler, sahip olduğu dış görünüş ve huyları nedeniyle eşek; genellikle, ona benzer olan atla karşılaştırıldığında hakaret etmek için insanların benzetildiği bir hayvandır. Eşekle karşılaştırılan at ise, zekâsı, dış görünüşü, hızı ve insana olan sadakati, nedeniyle iyi özellikleri olan insanlar için benzetilen bir hayvan olarak kullanılır.

Atasözü iki kısımdan oluşmaktadır. Birinci kısımda cilve yapması itici olacağı bilinen eşeğe cilve yap denmesiyle gerginlik yaratılmış ve merak uyandırılmış, ikinci bölümde ise eşeğin kendisinden beklenileni yapmasıyla gerginlik ortadan kaldırılmış ve merak giderilmiştir. Gerginliğin yaratıldığı cümlede, insanların hoşuna gitsin diye hoş sözler söylemeye çalışan kaba ve ahmak kişiler, sembolik olarak kaba ve ahmak olarak kabul gören eşeğe benzetilerek aşağılanmıştır. Atasözündeki mizahi unsurun temelinde aşağılama durumu vardır. Alaya alma hedefini güden eşeğin kullanılarak anlatıldığı bu durum, alaya maruz kalan kişiyi yani 2. kişiyi düşürürken olayı anlatanın (1. kişinin) ve olayı dinleyenin (3.kişinin) üstünlük duygusuna kapılmasını sağlar. Gerginliğin giderildiği cümlede ise cilve yap isteğine karşı çifte atılması, hoş bir şey olan cilve ile sert bir şey olan çiftenin karşıtlığından ve uyumsuzluğundan yararlanılmıştır. Kaba ve ahmak bir kişinin bu eksikliklerini giderme amacıyla yaptığı şirin davranışlar ters tepebilir ve daha büyük bir eksikliğe sebep olabilir. Atasözündeki mizahi unsur şirin davranış sonucu oluşabilecek olan eksikliği telafi etmek amacıyla kullanılmıştır. 
Bu bağlamda düşünüldüğünde atasözündeki mizahi unsur olan aşağılama üstünlük kuramıyla mizah tarzı olarak da saldırgan mizah tarzı ile ilişkilendirilebilir.

3. Atasözü: "Aptessiz 5 sofuya namaz mi dayanır? " (s. 79)

3. Atasözünün Anlamı: "Gerekli koşulları yerine getirilmedikten sonra az zamanda pek çok iş yapılır." (s. 79)

\section{Atasözünün Mizahi Yönden İncelemesi:}

Nesneler, bu nesnelerin nitelikleri, olaylar, vs. arasında kalıpların bulunmasını beklediğimiz düzenli dünyada yaşamaktayız. Bu kalıplara uyuşmayan herhangi bir şey başımıza geldiğinde güleriz. Pascal'ın belirttiği gibi, " Kişiyi umduğuyla bulduğu arasındaki şaşırtıcı orantısızlıktan başka hiçbir şey daha fazla güldürmez (Akt. Moreall, 1997, s. 25). Abdestli olmak namaz ibadetinin şartlarından biridir, abdestsiz bir kişinin, üstelik bir sofunun namaz kılması namaz-abdest-sofu arasındaki kalıplaşmış ilişkinin kırılması demektir.

Atasözündeki mizahi unsur "apdestsizlik" sofu ve namaz kelimeleri arasındaki uyumsuzluktur. Gerekli koşulları yerine getirmeme durumu, abdest almama ile az zamanda yapılan çok ama etkisiz iş, abdestsiz kılınan namazla, ilişkilendirilmiştir. Atasözünde bir işe koyulurken o iş için gerekli hazırlıkların yapılmaması durumu eleştirilmektedir. Mizahi unsuru yaratan uyumsuzluk gerekli koşulların yerine getirilememesi sonucu oluşan eksikliğin telafisi üzerine oluşmuştur. Eksikliği gidermek için yapılan eleştiri saldırgan bir amaç güder. Bu bağlamda atasözündeki mizah unsuru; mizah tarzı bakımından saldırgan mizah tarzıyla, mizahi unsurun güldürme sebebini ise uyumsuzluk kuramı ile açıklanabilir.

4. Atasözü: "Çingeneye beylik vermişler, önce babasını kesmiş" (s. 111)

4. Atasözünün Anlamı: "Ne oldum delisi soysuz kişi, eline yetki geçince, en yakınlarına kötülük yapmakla işe başlar." (s. 111)

Ne oldum delisi soysuz kişi tabiri ön yargılı ve abartılı bir tabirdir. Bu yüzden "Ne oldum delisi soysuz kişi", tabirini "yetkiyi hak etmeyen insan" olarak düzeltmek bize göre daha uygundur.

\section{Atasözünün Mizahi Yönden İncelemesi:}

Kendilerine karşı fiziksel cesaret zeka ya da başka insani özellik konusunda üstünlük duyduğumuz kişilere güleriz, bu ise onları alaya almaktır. (Morreall, 1997, s. 22). Bu alaya alma savunma ya da saldırı hedefiyle olabilir ve alaya alma sonucu kişi bir rahatlama duyar.

Atasözü iki bölümden oluşmaktadır. İlk cümlede aşağılanmayı hak eden birine beylik verildiği söylenerek gerginlik yaratılmış, ikinci cümlede ise gerginlik, bu kişinin kendisinden

\footnotetext{
${ }^{5}$ Bu kelime kaynak eserde bu şekilde geçmektedir.
} 
beklenilen şeyi yaptığı görülünce, kaybolmuş, rahatlama meydana gelmiş ve bu rahatlamayla beraber gülmenin ortaya çıkması mizah unsurun oluşmasını sağlamıştır. Ayrıca atasözündeki mizahi unsurun verdiği rahatlamada bir baskının boşalımı değil, bir üstünlügün fark edilmesi durumu vardır ve karşısında üstünlük hissedilen kişi aslında Çingene değil, Çingene gibi olan kişidir. Görüldüğü gibi diğer atasözlerinden farklı olarak bu atasözünde azınlık olarak yaşayan ve kendilerine has bir takım özelliklerinden veya azınlıkta olmanın doğurduğu güçsüzlükle ezilmiş ve ötekileştirilmiş olan bir topluluğun adı kullanılarak yapılan hakaret eylemi vardır. Bu eylem aşağılanmayı hak eden bir kişinin üst bir konuma gelmesiyle toplumda oluşan rahatsızlığı yani eksikliği telafi etmek amaciyla kullanılmıştır.

$\mathrm{Bu}$ bağlamda düşünüldüğüne atasözündeki mizahi unsuru üstünlük kuramıyla mizah tarzını ise alaya alma, aşağılama nedeniyle saldırgan mizah tarzıyla ilişkilendirilebilir.

5.Atasözü: "Gavurun tembeli keşiş, Müslümanın tembeli derviş olur."(s. 129)

5.Atasözünün Anlamı: "Hıristiyanlar arasında keşişler, Müslümanlar arasında dervişler tembel kişilerdir. Çünkü bir köşeye çekilip otururlar; onun bunun verdikleriyle geçinirler." (s. 129)

\section{Atasözünün Mizahi Yönden İncelemesi:}

Atasözünde düşman olarak kabul edilen dervişi, Freud'un dediği gibi aşağılık çirkin, hor görülmesi gereken kimse olarak sergilenip, bu yakıştırmadan bedava zevk sağlaması beklenen kişinin gülüşleri ve alayları sayesinde düşmanı bozguna uğratma gibi amaç vardır (Freud, 1999, s. 81). Derviş olmak için belli bir eğitimden geçmek, belli başlı yollardan gitmek ve çok fazla sabır göstermek gerektiği bilinmesine rağmen bu aşamaların hepsi tamamen görmezden gelinerek saldırdığı hedefin marifetleri küçük düşürülmüş ve dikkatler dervişlerin karşılıksız bir şeyler almasına çekilerek hedefin tek marifetinin tembellik olduğu vurgulanıp, dervişi aşağılamaya yönelik bir tutum sergilenmiştir. Keşişler ise dervişlerin Hıristiyan versiyonlarıdır ve aynı nedenlerden ötürü bu aşağılamaya onlarda maruz kalmışlardır. Atasözünün ilk cümlesinde gavur ikinci cümlesinde Müslüman kelimesinin kullanımı aslında toplumlara gönderme yapmaktadır ve peşlerinden gelen keşiş ve derviş kelimeleri bu tür insanların her toplumda olabileceğini göstermektedir. Ayrıca gavur ve Müslüman kelimeleri karşıtlıklarıyla, keşiş ve derviş kelimeleri ise ses ve kavram benzerlikleriyle atasözünde akılda kalıcılığı sağlamak için kullanılmışlardır.

Atasözündeki mizahi unsur dervişlerin halktan karşıllksız bir şeyler almasına bir çeşit sövgü tekniğiyle verilen tepkidir. Bu tepki dervişlere karşı oluşan tahammül eksikliğini telafi etme amacıyla kullanılmıştır. Bu bağlamda atasözündeki mizahi unsuru rahatlama kuramıyla mizah tarzını ise saldırgan mizah tarzıyla ilişkilendirebiliriz. 


\section{ATASÖZLERININ SINIFLANDIRILMASI}

İncelenen atasözleri mizah kuramları ve mizahın yaratılmasına zemin hazırlayan eksikliklere göre sınıflandırılabilir. Mizah kuramları açısından bakıldığında birinci atasözünde mizah; boşaltım organı olan ve cinsel bir çağrışım yaratan götün bahsi ile yaratıldığ1 için rahatlama kuramıyla, ikinci atasözünde mizah; kaba ve güzel olmayan bir hayvana yapılan benzetmeyle gerçekleştirilen aşağılama ile yaratıldığ1 için üstünlük kuramıyla, üçüncü atasözünde mizah; abdestsizlik, namaz ve sofuluk kavramları arasındaki uyumsuzluktan yararlanılarak yaratıldığı için uyumsuzluk kuramıyla, dördüncü atasözünde mizah; bir ırka benzetilerek yapılan aşağılamayla yaratıldığı için üstünlük kuramıyla, beşinci atasözünde ise mizah; belli bir toplumsal sınıfa mensup kişilere yapılan saldırgan bir eleştiri aracılığıyla yaratıldığı için rahatlama kuramıyla ilişkilendirilebilir.

Her kültür unsuru gibi mizah da herhangi bir eksikliği telafi etmek ve bazen önlemek amacıyla yaratılmıştır. Atasözlerinde var olan mizahın zemin hazırladığı eksiklikler ise atasözlerinin yaratılmasına sebep olan eksikliklerle genellikle aynıdır ve mizahın eksikliğin telafisine yardımcı olduğu görülmektedir. Eksiklikler telafi edilme şekilleri sonucu oluşan üstünlük, uyumsuzluk ve rahatlama durumları meydana gelmiş, gülmeyi amaçlayan mizah yaratımı bu üç durum doğrultusunda oluşmuştur. Atasözleri ve mizahın yaratılmasına sebep olan eksiklikler genellikle toplumun kurallarını bozan, toplumu rahatsız eden durumlardan ötürü doğan eksiklikledir. ${ }^{6}$

Bireyin uygunsuz davranışları sonucu toplumun bireyde gördüğü eksiklikler bağlamında birinci atasözünde ahlak eksikliği ikinci atasözünde kabalık ve ahmaklık, üçüncü atasözünde ise bir işin gerektirdiğini yapmama gibi eksiklikler söz konusudur. Dördüncü atasözü toplumun kendi içinde gördüğü eksiklikler bağlamında değerlendirilebilecek liyakat sisteminin bozulması sonucunda oluşan tahammül eksikliğinin telafisi vardır. Beşinci atasözünde toplumun herhangi bir bireyde gördüğü uygunsuz davranışın toplumda yarattığ eksiklik bağlamında düşünülebilecek bir durum, dervişlere karşı oluşan tahammül eksikliği söz konusudur.

Eksiklikleri telafi etmek için kullanılan saldırgan mizah tarzı ise toplumun bu tür eksikliklere karşı tahammülünün olmadığını göstermektedir. Bu bağlamda atasözlerindeki saldırgan mizah tarzı muhatabı olan kişiyi aşağılayıp küçük düşürürken aynı zamanda aktarıldığı gelecek kuşaklara mesaj vermektedir. Diğer taraftan bakıldığında eksikliğe neden olan kişiye yapılan saldırı atasözünü aktaran ve atasözünün muhatabı olmayan kişileri

\footnotetext{
6 İncelenen atasözleri artıkça atasözlerinin ve atasözlerindeki mizahın telafi ettikleri eksiklik durumların sayısı artabilir. Elli dokuz atasözünü incelediğimiz Atasözlerinde Mizahın İşlevi adlı yayımlanmamış yüksek lisans tezimizde bahsi geçen durumların yanında toplumun bir şeylere karşı çaresiz kalmasından ötürü doğan eksikliklerin de giderildiği tespit edilmiştir.
} 
rahatlatmaktadır. Bu bağlamda düşünüldüğünde iki farklı saldırgan mizah tarzı olduğunu söylemek mümkündür. Biri toplumun menfaatlerini koruyan saldırgan mizah tarzı diğeri ise rahatlama amacıyla gerçekleşirken yıkıcı bir tavır gösteren saldırgan mizah tarzı. Birinci tarzda toplum düzeninin veya algısının dışına çıkan kimseler küçük düşürülüp bu küçük düşürülme sonucu kişinin tekrar düzene dâhil olması amaçlanır. İkinci tür saldırgan mizah tarzında ise aşağılama, hakaret etme, cinsel çağırışımlar yaratma gibi eylemlerle karşı tarafı bozma ve rahatlama amaçlanır. Birinci tip saldırgan mizah tarzı Bergson'un görüşlerine dayanırken ikinci tip saldırgan mizah tarzı ise Freud'un görüşlerine dayanmaktadır. İncelenen atasözlerinde Bergson'un görüşüne dayandırılabilecek saldırgan bir mizah tarzı olan atasözleri birinci ve dördüncü atasözleridir. İkinci üçüncü ve beşinci atasözleri Freud'un görüşüne dayandırılabilecek saldırgan bir mizah tarzına sahip atasözleridir.

İncelenen atasözleri sinıflandırıldıktan sonra atasözlerinde saldırgan mizah tarzının işlevi tartışılabilir.

\section{TARTIŞMA; ATASÖZLERİNDE SALDIRGAN MİZAH TARZININ ISŞLEVİ}

Atasözü üzerine inceleme yapan araştırmacıların atasözleri hakkında görüş birliğine vardığı konu; atasözlerinin sözlü kültür devrinde toplumun okulu ve yaşama kılavuzu olduğu gerçeğidir. Atasözleri toplumun hayatta kalma mücadelesindeki tecrübesinin gelecek kuşaklara aktarılması görevini, yazının icadı ile beraber okullara; bununla beraber yazının olmadığı geleneksel toplumlardaki üst kuşak veya yaşlı/ bilge kişiler ise yerini öğretmenlere bırakmışlardır.

Bilginin aktarılmasını sağlayan geleneksel unsurlar, yazının icadı ile beraber her ne kadar yerini modern unsurlara bıraksa da, bilginin aktarılmasında kullanılan yöntemlerden biri olan mizah kullanımı hâlâ devam etmektedir. Bu nedenle eğitim bilimleri uzmanları tarafından son yıllarda ciddi bir şekilde araştırılan "bir öğretim tekniği olarak mizahı kullanma durumu" ve bu araştırmalar sonucu ortaya çıan sonuçlar atasözleri ve mizah arasındaki ilişkinin anlaşılmasında yardımcı olacaktır. İnceleme ve sınıflandırma bölümlerinden elde ettiğimiz verilere göre atasözlerinin toplumun kendisinde ve herhangi bir bireyde hissettikleri eksikliğin yanı sıra bireyin kendisinde hissettiği eksiklikleri telafi etme ve önleme amacı vardır. Yazı ve yazıyla beraber gelişen modern eğitim de bu tür eksikleri telafi etme ve önleme amacıyla icat edilmiş ve geliştirilmiştir. Bu nedenle yazının icadı ile beraber gelişen modern eğitim geleneksel bir eğitim yöntemi olan atasözlerinde kullanılan mizah da aynı amaçla kullanılmış olabilir.

Lowis, mizahın sosyal ilişkilerin kurulmasında arabuluculukta ve saldırganlığın örtülü anlamının algılanmasında, stresle başa çıkmada ve son olarak eğitim ve öğretimde olmak üzere 4 ana alanda olumlu olarak kullanılabileceğini ifade etmiştir (Oruç, 2010, s. 59). 
Lowis' in bu görüşünü atasözlerinin eğitici boyutu düşünülerek tekrar okuduğunda biraz önce yapılan tahmin daha da kesinleşmektedir. Yani bir eksikliğin tamiri için yaratılan atasözü, mizah kullanılarak yaratıldığında, mizah bu eksikliğin telafisinde yardımcı olur. Bu durumda mizahın yaratılmasına ve atasözlerinin yaratılmasına sebep olan eksiklik aynıdır. Sonuç olarak 4 alandan biri olan eğitim ve öğretim alanı atasözleri ve mizahın atasözlerindeki işlevi ile ilgilidir.

Atasözlerinde eksikliği telafi etmek için yaratılan mizahın genelde üstünlük ve rahatlama duygularının verdiği hazzı tetiklemeyle yaratıldığı görülmektedir. Bu hazzı tetiklemek amacıyla alaya alma, aşağılama, hakaret etme, cinselliği çağrıştıracak kelimelerle ayrıca üreme ve boşaltım organlarıyla yapılan saldırılarla gerçekleştirilmiştir. Yani eksiklikler karşı saldırılarla giderilmeye çalışılmıştır. Atasözlerindeki saldırgan mizah tarzı atasözlerinin eğitim öğretim işlevine engel olmamıştır.

Bir eksikliği telafi eden atasözlerinin icra edildiği sırada ilk endişesi dikkat çekmek ve mesajı karşısındakilere eksiksiz bir biçimde aktarmaktır. Eğitim bilimleri uzmanlarının öğretim tekniği olarak mizah kullanımında da mizahın dikkat çekici yönünden bahsedilmektedir.7 Örneğin açık göte herkes tükürür atasözünde göt kelimesinin bahsi ile yaratılan mizah, mesajı alanın dikkatini çekmiştir. Kinaye ve istiare gibi sanatlarla ayıplanacak harekeler götle ilişkilendirilmeseydi verilmek istenilen mesaj bu kadar dikkat çekmezdi. Dikkat çekme düzeyi düşük olduğu için de anlaşılması ve giderilmek istenen eksikliğin telafisi zorlaşırdı. Bu nedenlerle atasözünde bulunan mizahın ilk işlevinin, modern eğitimde kullanılan mizah gibi ilk işlevinin dikkat çekme olduğu söylenebilir.

Atasözleri dikkat çektikten sonra anlaşılmayı bekler. Yazının olmadığı bir devirde bilginin anlaşılması için kısa ve öz kalıplar yaratılması bazı kelimelerin veya seslerin tekrar tekrar kullanılması sözlü kültür ürünlerinde yaygındır. Modern öğretme tekniklerinde ise şaka veya mizahi hikâyeler anlatıldığında öğrencilerin yeni konuyu daha iyi anladığ savunulmaktadır ( Oruç, 2010, s. 61). Hikâye anlatma durumu Ömer Asım Aksoy'un öykü biçimindeki atasözleri şeklinde tanımladığı atasözlerinde sık sık görülür ki incelenen atasözlerinden ikincisi ve dördüncüsü bu tarz bir atasözüdür. Bu atasözlerinde verilmek istenen bilgi, tek cümlelik bir hikâyeden sonra ortaya çıkmaktadır. Örneğin; ikinci atasözündeki eşeğe cilve yap demişler ve dördüncü atasözündeki çingeneye beylik vermişler, cümleleri birer hikâyedir. Bu hikâyelerde bulunan mizah anlaşılmayı kolaylaştırmıştır. Hikâyelerde kullanılan eşek ve çingene kelimeleri mizahın oluşmasında ve mesajın anlaşılmasında önemli bir işlevi olan anahtar kelimelerdir

\footnotetext{
${ }^{7}$ Haslem: "Mizah dikkat çekmenin etkili bir yoludur. Öğrencilerin ekstra enerjilerini boşaltır ve bir grup hâline gelmelerini sağlar" (Akt. Oruç, 2010: 61)
} 
Atasözlerinin bir diğer endişesi akılda kalmadır. Modern öğretim tekniklerinde mizah kullanımın bir işlevi de bilgiyi hatırlamaya dönük yardımıdır. Steele, öğrencilerin problemlerini alışık olmayan yollarla anlatan öğretmenlerini hatırlama eğiliminde olduğunu söylerken; Oruç, dersi pekiştiren bir şaka yapmanın, mizahı bir çağrışımla ana fikri hatırlamaları için öğrencilere yardımcı olacağını savunur.(Akt. Oruç, 2010, s. 59; Oruç, 2010, s. 61) Örneğin; Abdestsiz sofuya namaz mı dayanır? atasözündeki gibi alışılmamış ilişkilendirmeler sonucu oluşan mizah, hatırlanmada ve kalıcı olmada etkili olmuştur.

Mizahın atasözlerindeki bu üç işlevi aslında dördüncü bir işlevi de beraberinde getirir. Dikkat çeken, anlaşılan ve hatırlanan bir bilginin doğal olarak daha önceden aktarılması gerekir. Atasözlerinin değişmez ve kalıpsal yapılar olduğu düşünüldügünde bu aktarım sırasında mizahın unsurlarında korunduğu ve aktarımda mizahın da büyük bir payı olduğunu söylenebilir.

\section{SONUÇ}

Sonuç olarak; atasözlerinde üstünlük uyumsuzluk ve rahatlama kuramları ile tanımlanan ve saldırgan bir tarzda olduğu tespit edilen mizahi unsurların atasözlerinin yaratılmasına sebep olan eksiklikleri telafisi için atasözlerine yardımcı olduğu tespit edilmiştir. Bu eksikler toplumun kendisinde gördüğü, toplumun bireyde gördüğü ve bireyin kendisini istemediği bir durumda bulması sonucu oluşan eksikler olduğu görülmüştür. Atasözlerinde bir takım eksikleri telafi etmek için genellikle bir hayvan veya üreme ve boşaltım organlarıyla yapılan ilişkilendirmeler başta olmak üzere; küçük düşürmeye dönük bir anlayışla yaratılan saldırgan mizahın, atasözlerinin; bilgiye dikkat çekme, anlaşılmasını sağlama, hatırlama ve aktarma eylemlerine yardımcı olmak gibi bir işlevi olduğu anlaşılmıştır.

\section{KAYNAKÇA}

Akgöl, A. (2016). 2016). Atasözlerinde Mizahın İşlevi. Yüksek Lisans Tezi. Muğla: Muğla Sıtkı Koçman Üniversitesi.

Aksan, D. (1996). Türkçenin Söz Varlı̆̆ı. Ankara: Engin Yayınevi.

Aksoy, Ö. A. (1988). Deyimler ve Atasözleri Sözlü̈̆̈̈̈ 1. İstanbul: İnk1lap Kitapevi.

Baudelaire, C. (1997). Gülmenin Özü. (İ. Yalçın, Çev.) İstanbul: İris Yayıncılık.

Bergson, H. (2011). Gülme. (Y. Avunç, Çev.) İstanbul: Ayrıntı Yayınları.

Çobanoğlu, Ö. (2003). Türk Dünyası Ortak Atasözleri Sözlü̆̆̈̈. Ankara: AKM Yayınları.

Devellioğlu, F. (2010). Osmanlıca Türkçe Ansiklopedik Lûgat. Ankara: Aydın kitapevi.

Feingberg, L. (2004). Mizahın Sırrı. Millî Folklor (62), s. 10-113.

Freud, S. (1999). Espri Sanatı. (E. Alkan, Çev.) İstanbul: Toplumsal Dönüşüm Yayınları. 
Kortantamer, T. (2007). Temmuzda Kar Satmak. Ankara: Phoenix Yayınları.

Morreall, J. (1997). Gülmeyi Ciddiye Almak.(Ş. S. Kubilay Aysevener, Çev.) İstanbul.

Ong, W. J. (2010). Yazılı ve Sözlü Kültür: Sözün Teknolojileşmesi. (S. P. Banon, Çev.) İstanbul: Metis Yayınları.

Oruç, Ş. (2010). Sosyal Bilgiler Öğretiminde Mizah Kullanımının Öğrencilerin Akademik Başarılarına ve Tutumlarına Etkisi. Mehmet Akif Ersoy Ünivesitesi Sosyal Bilimler Enstitüsü Dergisi, s. 56-73.

Oy, A. (1972). Tarih Boyunca Türk Atasözleri. İstanbul: Türkiye İş Bankası Kültür Yayınları.

Öngören, F. (1983). Türk Mizahı ve Hicvi. Ankara : İş Bankası Yayınları.

Özdolap, M. (2015). Mizah Tarzları ve Psikolojik Belirtiler Arasındaki İlişkinin İncelenmesi. Yüksek Lisans Tezi. Bilim Üniversitesi. İstanbul

Özünlü, Ü. (1999). Gülmecenin Dilleri. Ankara : Doruk Yayınları.

Sanders, B. (2001). Kahkahanın Zaferi- Yıkıcı Tarih Olarak Gülme. (K. Atakay. Çev.). İstanbul: Ayrıntı Yayınları.

Yerlikaya, E. E. (2009). Üniversite Öğrencilerinin Mizah Tarzları İle Algılanan Stres, Kaygı ve Depresyon Düzeyleri Arasındaki İlişkinin İncelenmesi. Doktora Tezi, Çukurova Üniversitesi. Adana.

TDK (1998). Türkçe Sözlük. Ankara: Türk Dil Kurumu Basımevi. 